\title{
Sacrifice for (not) buying: how to measure sacrifice in the consumer context
}

\author{
Sacrifício para (não) compra: como mensurar o sacrifício no contexto do consumidor \\ Sacrificio por (no) compra: cómo medir el sacrificio en el contexto del consumidor
}

Received: 10/08/2021 | Reviewed: 10/15/2021 | Accept: 10/16/2021| Published: 10/19/2021

\author{
Jairo de Pontes Gomes \\ ORCID: https://orcid.org/0000-0003-2658-0317 \\ Federal University of Paraiba, Brazil \\ E-mail: jairo@ccs.ufpb.br \\ Salomão Alencar de Farias \\ ORCID: https://orcid.org/0000-0001-5415-2606 \\ Federal University of Pernambuco, Brazil \\ E-mail: saf@ufpe.br \\ Marianny Jessica de Brito Silva \\ ORCID: https://orcid.org/0000-0001-5567-3657 \\ Federal University of Pernambuco, Brazil \\ E-mail: marianny.brito@ufpe.br
}

\begin{abstract}
This paper describes what the sacrifice is for consumption and proposes a scale to measure the sacrifice for (not) buying products. A multimethod approach was applied to achieve the proposed objectives. Initially, three qualitative studies were carried out (two focus groups and one interview with experts). Then, three quantitative studies were conducted (two online and a survey), and finally, two factorial experiments, $2 \times 2$ were developed. The act of sacrifice was understood as an exchange process in which some kind of benefit is sought, a fact that also consolidates the definition of sacrifice presented as the willingness to give up something that has value (monetary or not) in order to obtain some benefit (emotional and/or material) of greater importance. Furthermore, the existence of positive and negative elements in the sacrifice for (not) buying products, described as valence and instrumentality, respectively, was identified. It was also found that different levels of valence and instrumentality affect purchase intent. The elements that comprise the sacrifice for (not) buying products were presented, highlighting a definition that can reduce the doubts about what sacrifice is in the context of consumption, as well as how to measure it.
\end{abstract}

Keywords: Sacrifice for (not) Buying; Scale development; Valence; Instrumentality.

\section{Resumo}

Este artigo descreve o que é o sacrifício no consumo e propõe uma escala para medir o sacrifício para (não) compra de produtos. Uma abordagem multimétodo foi aplicada para atingir os objetivos propostos. Inicialmente, foram realizados três estudos qualitativos (dois grupos focais e uma entrevista com especialistas). Em seguida, foram realizados três estudos quantitativos (dois online e um survey) e, por fim, foram desenvolvidos dois experimentos fatoriais, $2 \times 2$. $\mathrm{O}$ ato de sacrifício foi entendido como um processo de troca em que se busca algum tipo de benefício, fato que também consolida a definição de sacrifício apresentada como a disposição de abrir mão de algo que tem valor (monetário ou não) para obter algum benefício (emocional e/ou material) de maior importância. Além disso, foi identificada a existência de elementos positivos e negativos no sacrifício para (não) compra de produtos, descritos como valência e instrumentalidade, respectivamente. Também foi descoberto que diferentes níveis de valência e instrumentalidade afetam a intenção de compra. Foram apresentados os elementos que compõem o sacrifício pela (não) compra de produtos, destacando-se uma definição que pode reduzir as dúvidas sobre o que é sacrifício no contexto do consumo, bem como a forma de medi-lo.

Palavras-chave: Sacrifício para (não) compra; Desenvolvimento de escala; Valência; Instrumentalidade.

\section{Resumen}

Este artículo describe cuál es el sacrificio por el consumo y propone una escala para medir el sacrificio por (no) comprar productos. Se aplicó un enfoque multimétodo para lograr los objetivos propuestos. Inicialmente se realizaron tres estudios cualitativos (dos grupos focales y una entrevista a expertos). Luego, se realizaron tres estudios cuantitativos (dos online y una encuesta), y finalmente, se desarrollaron dos experimentos factoriales, $2 \times 2$. El acto de sacrificio se entendió como un proceso de intercambio en el que se busca algún tipo de beneficio, hecho que también consolida la definición de sacrificio presentada como la disposición a renunciar a algo que tiene valor (monetario o no) con el fin de obtener algún beneficio. (emocional y / o material) de mayor importancia. Además, se identificó la existencia de elementos positivos y negativos en el sacrificio por (no) comprar productos, descritos como valencia e instrumentalidad, respectivamente. También se encontró que los diferentes niveles de valencia e instrumentalidad 
afectan la intención de compra. Se presentaron los elementos que componen el sacrificio por (no) comprar productos, destacando una definición que puede reducir las dudas sobre qué es el sacrificio en el contexto del consumo, así como cómo medirlo.

Palabras clave: Sacrificio por (no) Comprar; Desarrollo de escala; Valencia; Mediación.

\section{Introduction}

Sacrifice is a theme that is present in the daily lives of consumers. On the one hand, some people are willing to make a sacrifice to obtain a particular good or service by giving up activities that bring them pleasure. On the other hand, some consumers are likely to make a sacrifice by not acquiring products, such as individuals who fail to buy their favourite products because of environmental concerns (Rahman \& Reynolds, 2016; Hüttel, Ziesemer, Peyer \& Balderjahn., 2018) or due to a lack of discretionary income. However, analysing the role of sacrifice in consumption is not an easy task. One of the main difficulties was evidenced by James (1933), who stated that sacrifice belonged to many areas of research. Therefore, there is no single way of visualizing this construct that adequately explains all the points of view from which it can be considered (Bubbio, 2013; Matear, 2014; Kearns, 2016).

In the area of marketing, contributions to the understanding of sacrifice include the influence of the anthropological approach. For example, Halbertal (2012) indicates that the korban, an ancient Hebrew term for sacrifice, was considered a gift, an offering given by humans to the gods. Subsequently, the term came to mean giving up a vital interest for a greater cause. Finally, the third sense of sacrifice refers to it not only as an offering but also as a victim of a crime. Such anthropological perspectives gave rise to the main conceptions of sacrifice in the marketing context. Evans-Pritchard (1956) considered sacrifice as an essential component in the overall process of exchange. Bataille (1988) highlighted the relationship of sacrifice to consumption; and, later, Miller (1998) drew a parallel between sacrifice and the making of purchases.

More recently, according to Matear (2014), the marketing literature has tended to associate the concept of sacrifice with three other constructs: market exchange, sharing, and gift-giving. Even considering that such constructs have similar elements to sacrifice, there are differences among them that need to be highlighted, especially in the context of consumption. More specifically, in the consumer behaviour literature, this diversity of perspectives is also found, as some authors consider sacrifice to be a component of the perception of value. Perceived value is represented by a relationship between benefit received and sacrifice made (e.g., Monroe \& Krishnan, 1985; Dodds, Monroe \& Grewal, 1991; Beldona \& Kher, 2014; Koch \& Sauerbronn, 2018). Another current perspective is that sacrifice is linked to the monetary aspect of the buying process, constituting the price that consumers pay (e.g., Zeithaml, 1988; Teas \& Argawal, 2000; Gao, Zhang \& Mittal, 2015). In addition to these definitions, a third group of authors understands that sacrifice is related to gift-giving (e.g., Miller, 1998; Belk, 2010). Finally, a fourth view believes that sacrifice is the difference between what the customer wants and what he is content to have (e.g., Pine \& Gilmore, 2000).

The multiplicity of perspectives on sacrifice led to a need for systematization of knowledge to delimit the scope of this construct in the field of consumer behaviour. By analysing different conceptions of sacrifice in the literature, it was concluded that there is, directly or indirectly, a common element in all of them: the search for some benefit; even when giving the gods a sacrifice, primitive people sought to obtain favours (Frazer, 1894; Hubert \& Mauss, 1898; Tylor, 1871a). The individual who sacrifices as a gift seeks some personal return (Mauss, 2002; Schmidt, 2013; Sherry Jr., 1983).

The different perspectives with which the word sacrifice can be used make it difficult to understand the term and may have limited the development of studies that address the theme in the context of consumption. Identifying this limitation as an opportunity to contribute to the advancement of knowledge in the area, this article focuses on these gaps by seeking to systematize the sacrifice for consumption, in addition to developing a theoretical model that can better highlight this phenomenon. A direct consequence of this process was the construction of an instrument to measure sacrifice for (not) buying. 


\subsection{Sacrifice Theories}

Sacrifice theories are as old as religions, and their interpretations may vary according to local culture and context. According to Watts (2011), etymologically, the meaning of the term sacrifice is 'to become sacred', and its origin derives from the Latin sacrificium, which is a composition of the words sacer (sacred) and facere (to make).

In general terms, the first conceptions of this word were strongly linked to the religious dimension and were developed from an anthropological perspective. One of the pioneers in the study of sacrifice, Sykers (1748, p. 4), defined it as "whatever is given or offered in a Solemn manner immediately to God, so that a part of it, or the whole is consumed". This vision provided the basis for the development of conceptions of sacrifice as a form of communion and gift for divinity (Carter, 2003).

Moreover, in his study of primitive culture, Tylor (1871b) considered that the understanding of sacrifice involved the manner in which the offering was transferred to divinity, proposing a genealogical theory that placed it in historical phases with three doctrines of sacrifice: gift theory, homage theory, and abnegation theory. For Tylor (1871b), the sacrifice was initially a gift that the savages gave to supernatural beings to secure their favour or minimize their hostility. In this way, the savages sought to indulge the deity from whom they expected something in return.

Expanding such perspectives and defining the nature and social function of sacrifice, Hubert and Mauss (1898, p. 13) proposed the following definition: "Sacrifice is a religious act which, through the consecration of a victim, modifies the condition of the moral person who accomplishes it or that of certain objects with which he is concerned". By this definition, the perception of sacrifice now encompasses the offering of inanimate items whose distinctive feature of consecration transfers it from the typical domain to the religious field; that is, sacrifice becomes a form of communication between the sacred and the profane through the mechanism of the victim or object sacrificed (Girard, 2005; Shilling \& Mellor, 2013).

In the economic view, one of the first perspectives is associated with equality of sacrifice (Mill, 1848), which means distributing the contribution of each person to government expenses, so that he shall feel neither more nor less inconvenience from his share of the payment than every other person experiences from his. The association of sacrifice with money and economy is as old as biblical accounts. In the early days of Greece, the most ancient measure of value was the sacrifice of a sacred bull as a tribute to be paid to the deity. In English, the word money has its origin in Greek mythology, whose derivation refers to Juno Moneta, sister and wife of the god Jupiter. At the temple of Moneta, every year, the sacred bull was sacrificed, and this temple was the place chosen to mint the first Greek coins (Desmonde, 1962). The association of money with sacrifice, represented in the figure of the bull (sacrificial animal), is still present today. On Wall Street, for example, the bull is the symbol of rising stock prices. (Keenan, 2005).

In turn, the psychological perspective of sacrifice generated associations with terms such as desire, love, and renunciation (Day \& Impett, 2017). However, it is also possible to verify the existence of the gift exchange component in all the concepts developed by the authors of this area. For example, in intimate relationships, by giving up something desired for the sake of the partner or relationship, the individual will seek some benefit, whether expressed in favours, companionship or even in material goods (e.g., Van Lange et al., 1997; Cahn, 1992; Moufahim, 2013; Komiya, Ohtsubo, Nakanishi \& Oishi, 2019).

The recognition that an individual's willingness to sacrifice is profoundly influenced by the personal belief system and prevailing cultural norms has directly impacted this marketing construct's perspective. Considering sacrifice as a process of exchange, Pine and Gilmore (2000) describe it in terms of gaps perceived by the client. For the authors, sacrifice is the difference between what the customer is content with and what exactly he wants or, in other words, the difference between what the customer accepts and what he or she needs. Taking as inspiration the anthropological conception that sacrifice was a gift to the gods, another marketing perspective associates sacrifice with gift giving (e.g., Clarke, 2007). In general, the 
literature tends to associate gift giving in terms of personal sacrifice. Thus, such action is undertaken to establish a social norm demonstrated in the commitment to give and receive reciprocally, often with rituals and ceremonies that can increase the perceived value of the present. This fact implies the recipient's perception of recognizing the obligation to return the gift at some future time, thereby generating an obligation (Mauss, 2002; Minowa \& Belk, 2019).

In general terms, the marketing view that approaches sacrifice as an element of the exchange process considers it to be a harmful component of the transaction (cost, effort, energy, etc.) (Cronin, Brady \& Hult, 2000; Gao et al., 2015; Williams, Ashill \& Thirkell, 2016; Rahman \& Reynolds, 2016; Koch \& Sauerbronn, 2018). According to Matear (2014), by focusing only on the negative elements of sacrifice, the transformational aspect, which benefits both the person who voluntarily sacrifices and the relationship itself, is ignored (Van Lange et al., 1997; Sherry \& Kozinets, 2007). Thus, the marketing literature now pays little attention to the notion that willingness to sacrifice can play a beneficial role in marketing relationships (Matear, 2014).

\subsection{Theoretical perspectives and hypotheses}

From the different perspectives of sacrifice, the existence of a common element that permeates the different motivations for the accomplishment of this act was verified: the search for a benefit. In this sense, Tylor (1871a) stated that the performance of the sacrifice is aimed at securing a favour or minimizing possible hostility. Thus, in seeking to appease divinity, one hoped to obtain something in return. For Smith (1894), the sacrificial death of a sacred animal and later consumption by the faithful was aimed at assimilating qualities of and seeking resemblance to the totem (god). That is, the sacrifice contemplated a process of exchange whose offering was the death of a sacred animal to absorb the qualities belonging to the totem. Mauss (2002) highlighted the element of exchange, noting that there is a reciprocity component in the purpose of destruction by sacrifice. From this perspective, Bataille (1988) emphasizes the social domain by stating that the purpose of giving in the act of sacrifice is to create a sense of obligation, in which the recipient must return it, possibly with some interest.

In all these approaches, it can be seen that the motivating factor for performing the sacrifice is to obtain some kind of benefit. However, Simmel (1990), Keenan (2005), and Ramp (2008) clarify that sacrifice is preceded by a path of suffering or death (of the individual or another person) on the way to a supreme moment. This finding reveals that in the performance of the sacrifice, there is a process of exchange in which the individual making the sacrifice seeks to obtain something superior (valued) by performing an effort represented by suffering or destruction (death). In the case of shopping, this path of suffering or destruction is characterized by renouncing something valued (loss/instrumentality) in favour of a good or service of higher value (benefit/valence).

Figure 1 - Sacrificial Action Model.

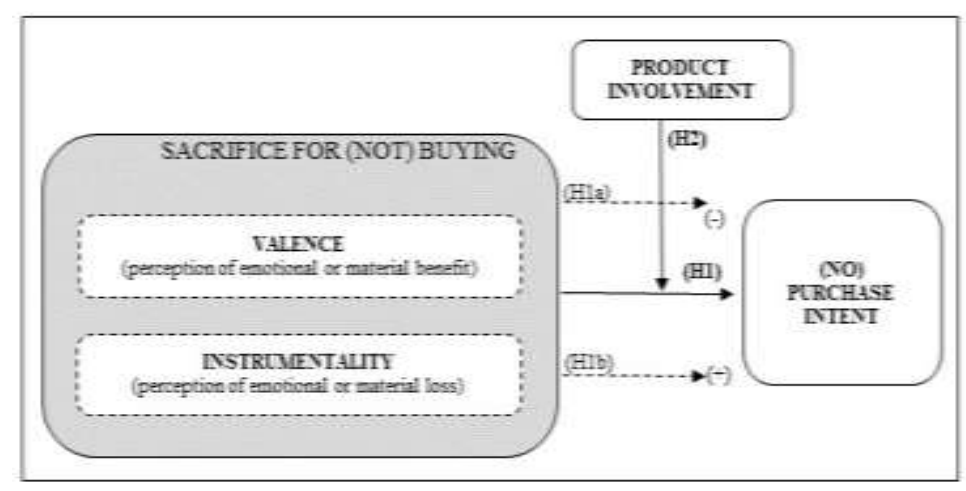

Source: Authors (2021). 
Given the above, and as presented in Figure 1, the hypotheses of research assume as hypothesis (H1) that the decision to make a sacrifice for (not) buying is formed by the relationship between valence (perception of emotional and/or material benefit) and instrumentality (perception of emotional and/or material loss).

As a consequence of this hypothesis, it was proposed as hypothesis (H1a) that valence (perception of emotional and/or material benefit) is negatively associated with the intention to sacrifice and that hypothesis (H1b): instrumentality (perception of emotional loss and/or material) is positively associated with sacrificial purchase intent. However, it is believed that the relationships exposed in hypotheses (H1a) and (H1b) acquire a new connotation when moderated by consumer involvement with the product, since, according to the marketing literature, involvement is perceived as the reflection of consumer needs, goals and values (Afonso, 2010; Celsi \& Olson, 1988). Thus, high involvement triggers a motivational process in the consumer that causes the use of resources necessary for the purchase of the product(s) considered fundamental to satisfy the objective or the need. Thus, in view of the above, the following hypothesis (H2) was developed: consumer involvement with the product moderates the intention to sacrifice for the purchase of goods and services.

\section{Methodology}

To achieve the proposed objectives, a series of studies was conducted contemplating different research methods and techniques, as described below. Initially, the theoretical basis was expanded through qualitative research operationalized by conducting interviews with experts in different areas of knowledge (marketing, psychology, anthropology, economics, sociology, philosophy, and religion) and two focus groups with consumers. In the analysis and interpretation of the collected data, content analysis based on the theory developed by Bardin (2011) was used. Then, through quantitative research, an instrument for measuring sacrifice for (non)purchase of goods and services was developed (Churchill, 1979; Netemeyer et al., 2003). Finally, the last phase included the design of the experimental project and the delineation of the scenarios used in three factorial experiments. This last phase fits into a kind of conclusive causal research.

\section{Results and Discussion}

\subsection{Study 1 - Outline of construct dimensions}

The research began with a qualitative study operationalized through interviews with experts (masters and doctors) in different areas of knowledge (administration, theology, marketing, psychology, anthropology, economics, sociology, finance, social work, engineering, physics, and philosophy). In all, seventeen interviews were conducted, all recorded with the consent of the informants and complemented with field notes. The average recording time was 12 minutes, discounting the presentation phase. Interviews were suspended in the 17th interviewee upon reaching theoretical saturation.

In the analysis and interpretation of the collected data, content analysis based on the theory developed by Bardin (2011) was used. Seeking to improve the data analysis, the progressive grouping of the first categories was performed, resulting in the emergence of seven intermediate categories. Finally, the intermediaries were brought together according to the consequences of the act of sacrifice, and these supported the conception of final two categories, called "Emotional and/or Material Benefit" and "Emotional and/or Material Loss", as presented in Figure 2. 
Figure 2 - Formation of Intermediate and Final Categories.

\begin{tabular}{|c|c|c|c|}
\hline Initial Category & $\begin{array}{c}\text { Intermediate } \\
\text { Category }\end{array}$ & Guide Concept & $\begin{array}{c}\text { Final } \\
\text { Category }\end{array}$ \\
\hline 1. Love & \multirow{3}{*}{ I. Feeling of worship } & \multirow{3}{*}{$\begin{array}{c}\text { Something or someone that is the target of affection, veneration } \\
\text { or exaggerated love }\end{array}$} & \multirow{12}{*}{$\begin{array}{l}\text { A) Emotional } \\
\text { and/or } \\
\text { material } \\
\text { benefit }\end{array}$} \\
\hline 2. Belief & & & \\
\hline 3. Dedication & & & \\
\hline 5. Choice & \multirow{3}{*}{ III. Exchange } & \multirow{3}{*}{$\begin{array}{l}\text { It indicates sacrifice as a process of exchange in which the } \\
\text { individual has a choice }\end{array}$} & \\
\hline 11. Ideal & & & \\
\hline 17. Renounce & & & \\
\hline 10. Need & IV. Need & Feeling that drives a person to do something & \\
\hline 8. Investment & V. Investment & Applying resource (money, time, energy, etc.) to earn a profit & \\
\hline 9. Maximize wellness & \multirow{4}{*}{ VI. Satisfaction } & \multirow{4}{*}{$\begin{array}{l}\text { Pleasure resulting from the accomplishment of what is expected } \\
\text { or desired }\end{array}$} & \\
\hline 15. Pleasure & & & \\
\hline 16. Achievement & & & \\
\hline 18. Overcoming & & & \\
\hline 4. Difficulty & \multirow{4}{*}{ II. Painful act } & \multirow{4}{*}{ Act that causes pain, suffering or discomfort } & \multirow{6}{*}{$\begin{array}{l}\text { B) Emotional } \\
\text { and/or } \\
\text { material loss }\end{array}$} \\
\hline 6. Effort & & & \\
\hline 7. Holocaust & & & \\
\hline 12. Suffering & & & \\
\hline 13. Feeling of loss & \multirow{2}{*}{ VII. Cost } & \multirow{2}{*}{ Loss associated with the act of sacrifice } & \\
\hline 14. Risk & & & \\
\hline
\end{tabular}

Source: Authors (2021).

\subsection{Study 2 - Development of the sacrifice measurement instrument for the purchase of goods and services}

The effort made to search for a sacrifice measurement scale in physical and electronic research sources did not yield the identification of a measurement instrument that could evaluate the sacrifice of (not) buying. Thus, a measuring instrument was developed to contemplate such a construct, using as inspiration the classical approach indicated by Churchill (1979) for the development of measures, employing multiple marketing constructs and incorporating elements of Netemeyer, Bearden \& Sharma (2003) proposal for the measurement and development of scales.

\subsubsection{Construct domain specification}

The scale development process was started by conducting exploratory research that aimed to generate greater knowledge about the sacrifice for consumption. For this aim, the literature review was used to identify items that have already been used in other studies and to conduct qualitative research. Thus, two focus groups were held in 2016, the first consisting of 12 postgraduate marketing students and the second consisting of 8 consumers. The results contributed to the generation of the dimensions of sacrifice associated with two perspectives (negative and positive). The negative perspective (loss) included the following dimensions: difficulty, suffering, risk, cost, price, renunciation, energy, time, effort, and life change. The dimensions associated with a positive perspective (benefit) were pleasure, sense of accomplishment, status, maximizing well-being, investment, and feeling of belonging.

\subsubsection{Item generation and validation}

The second phase was characterized by item generation (Churchill, 1979) and face and content validation activities (Netemeyer et al., 2003). To this end, five doctoral students in marketing, with knowledge in the development of measuring instruments, were invited to evaluate 139 generated items, classifying them in different dimensions. At the end of this process, 40 items remained, which were re-evaluated by two doctors in marketing.

To ensure a better refinement of the scale dimensions, a first sampling was performed containing the items considered by the experts as the most representative of each dimension. Data collection was performed using an online questionnaire. A total of 152 valid answers were obtained. The representative variables of the analysed dimensions were submitted for bivariate correlation analysis (Pearson) and exploratory factor analysis (EFA). In the extraction of the bivariate correlation matrix, we 
observed the items with a factorial load greater than 0.4 as indicative of dimensionality. For EFA, the dimensions were grouped according to the two perspectives of sacrifice presented (loss and benefit). For the first group, here called Instrumentality (loss), the initial analysis showed that three components met the Kaiser criterion of an eigenvalue greater than 1 and explained $60.26 \%$ of the variance. For the variables associated with the positive perspective of sacrifice, Valence (benefit), EFA presented only one factor with an eigenvalue greater than 1, comprising 50.49\% of the total variance. Based on the statistical analyses performed and the literature, the ten dimensions of the negative perspective of sacrifice (Instrumentality) were grouped into three new dimensions called Difficulty, Loss and Dissatisfaction. In the case of the positive perspective of sacrifice (Valence), the initial six dimensions generated only one factor, which led to grouping them into one dimension, called Realization. At the end of this phase, 19 items were considered fit to be included in the measurement instrument to be used in new data collection.

\subsubsection{Data Collection - Measurement Purification}

This step aimed to subject the set of items previously obtained to a sampling. A structured questionnaire (online via Google Docs) was used. Data collection included 183 respondents, of which 75 said they had not made a sacrifice to purchase. In this case, the sample for the composition of the statistical analysis was 108 respondents.

To verify the readjustment of the dimensions, statistical analyses were performed to examine the behaviour of the measurement items, eliminating those that did not present psychometric adequacy of bivariate correlation, internal consistency, and factorial adequacy. After these procedures, the result signalled that the remaining set of items was consistent and adequate to measure the sacrifice construct of (not) buying.

\subsubsection{Item Reduction and Dimensional Exploratory Investigation}

Aiming to perform new tests with the scale, another operationalized survey was conducted through personal interviews with 432 respondents at concentration points in the commercial centre of a Brazilian capital. A new structured questionnaire was used, containing the four remaining dimensions of the previous step and their respective items. The scale purification procedures consisted of extracting and verifying the correlation matrix of the variables by construct dimension, proceeding to confirmatory factor analysis (CFA), and assessing reliability. With the results obtained, the preliminary indication was that the scale was validated (Table 1). However, a definitive conclusion was only obtained by performing additional validity analysis procedures (Churchill, 1979). 
Table 1 - Confirmatory Factor Analysis.

\begin{tabular}{|c|c|c|c|c|c|c|}
\hline \multicolumn{5}{|c|}{ Panel 1 - Factorial Items and Scores } & Scores & CR* \\
\hline \multicolumn{7}{|c|}{ Variables - Difficulty } \\
\hline \multicolumn{5}{|c|}{ D1 - Buying this product prevented me from buying other items I want. } & 0,782 & ** \\
\hline \multicolumn{5}{|c|}{ D2 - To buy this product I had to give up other items I value. } & 0,824 & 10,656 \\
\hline \multicolumn{5}{|c|}{ D3 - To buy this product I had to reduce other expenses. } & 0,651 & 8,196 \\
\hline \multicolumn{5}{|c|}{ D4 - To buy the product I had to give up certain comforts. } & 0,832 & 10,577 \\
\hline \multicolumn{7}{|c|}{ Variables - Loss } \\
\hline & 0,825 & ** \\
\hline \multirow{2}{*}{\multicolumn{5}{|c|}{$\begin{array}{l}\text { Q2 - The purchase of the product made me delay the payment of other bills. } \\
\text { Q3 - To buy the product I had to perform activities that did NOT give me pleasure. }\end{array}$}} & 0,786 & 8,266 \\
\hline & & & & & 0,682 & 7,719 \\
\hline \multicolumn{7}{|c|}{ Variables - Realization } \\
\hline \multirow{3}{*}{\multicolumn{5}{|c|}{$\begin{array}{l}\text { R2 - Buying the product was a sign that I am a successful person. } \\
\text { R3 - Buying the product has provided me with emphasis with my friends and family. } \\
\text { R4 - Buying the product made me proud to be part of the group of owners of this product. }\end{array}$}} & 0,763 & ** \\
\hline & & & & & 0,802 & 8,746 \\
\hline & & & & & 0,819 & 8,555 \\
\hline \multicolumn{7}{|c|}{ Variables - Welfare } \\
\hline \multirow{4}{*}{\multicolumn{5}{|c|}{$\begin{array}{l}\text { B1 - Buying the product was important for my comfort. } \\
\text { B2 - Buying the product increased my well-being. } \\
\text { B3 - Buying the product has brought me advantages. } \\
\text { B4 - The effort to buy the product was offset by the gain I obtained. }\end{array}$}} & 0,741 & ** \\
\hline & & & & & 0,713 & 8,640 \\
\hline & & & & & 0,749 & 8,306 \\
\hline & & & & & 0,716 & 8,352 \\
\hline \multicolumn{7}{|c|}{ Panel 2 - Adjustment Measures } \\
\hline Adjustment Measure & Difficulty & Loss & Achievement & Welfare & \multicolumn{2}{|c|}{$\begin{array}{l}\text { Requirement / } \\
\text { adequacy }\end{array}$} \\
\hline Chi-square $(\chi 2)$ & 5,915 & 0,879 & 0,722 & 5,379 & \multicolumn{2}{|c|}{-} \\
\hline Degrees of freedom $(\mathrm{gl})$ & 2 & 1 & 1 & 2 & \multicolumn{2}{|c|}{-} \\
\hline Ratio $\chi 2 / g 1$ & 2,957 & 0,879 & 0,722 & 2,6895 & \multicolumn{2}{|c|}{$<5,000$} \\
\hline p-value & 0,052 & 0,348 & 0,396 & 0,068 & \multicolumn{2}{|c|}{$>0,050$} \\
\hline $\begin{array}{l}\text { Adjustment quality index - } \\
\text { GFI }\end{array}$ & 0,993 & 0,999 & 0,999 & 0,993 & \multicolumn{2}{|c|}{$>0.900$} \\
\hline $\begin{array}{l}\text { Comparative Adjustment } \\
\text { Index - CFI }\end{array}$ & 0,992 & 1 & 1 & 0,988 & \multicolumn{2}{|c|}{$>0.900$} \\
\hline Índice de Tucker-Lewis - TLI & 0,975 & 1,002 & 1,004 & 0,964 & \multicolumn{2}{|c|}{$>0.900$} \\
\hline $\begin{array}{l}\text { Standard Adjustment Index - } \\
\text { NFI }\end{array}$ & 0,987 & 0,995 & 0,997 & 0,981 & \multicolumn{2}{|c|}{$>0.900$} \\
\hline $\begin{array}{l}\text { Root of approximate mean } \\
\text { quadratic error - RMSEA }\end{array}$ & 0,068 & 0 & 0 & 0,063 & \multicolumn{2}{|c|}{$<0,080$} \\
\hline Variance explained & 60,135 & 58,762 & 63,19 & 53,265 & \multirow{2}{*}{\multicolumn{2}{|c|}{$\begin{array}{l}>50 \% \\
>0.70\end{array}$}} \\
\hline Cronbach's Alpha & 0,779 & 0,645 & 0,709 & 0,706 & & \\
\hline
\end{tabular}

* Meaning to $\mathrm{p}<0.001 ; * *$ Item with score set at 1 . Source: Authors (2021).

\subsubsection{Validity and reliability analysis}

This step aimed to confirm the validity and reliability characteristics. Usually, convergent and discriminant validity are presented. Regarding the convergent validity, the respective critical ratio (CR) measures were adopted, as shown in Table 1. Regarding the discriminant validity, it was found that the shared variance is lower than the extracted variance (Costa, 2011), a fact that occurred in all dimensions. Regarding the reliability check, the two measures (Cronbach's alpha and the compound reliability coefficient) were analysed as shown in Table 2.

Table 2 - Scale reliability measures.

\begin{tabular}{c|cccc|c}
\hline \multirow{2}{*}{ Measure } & \multicolumn{4}{|c}{ Dimension } \\
\cline { 2 - 5 } & Difficulty & Loss & Achievement & Welfare \\
\hline Cronbach's alpha & 0,779 & 0,645 & 0,709 & 0,706 \\
Composite & 0,857 & 0,809 & 0,837 & 0,820 \\
\hline
\end{tabular}

Source: Authors (2021). 
The results of the measurements indicate the existence of internal consistency, especially regarding the composite reliability presented for all scale dimensions, with values above 0.8 . Thus, after the procedures for verifying the psychometric characteristics of the scale, the result of this step included four dimensions, two linked to the negative perspective of sacrifice and two associated with the positive conception, as shown in Figure 3:

Figure 3 - Dimensions and Scale Items Buyer Sacrifice Indicator - BSI.

\begin{tabular}{|c|c|c|}
\hline Perspective & Dimension & Item \\
\hline \multirow{7}{*}{$\begin{array}{l}\text { Instrumental } \\
\text { ity }\end{array}$} & \multirow{4}{*}{ Difficulty } & will prevent you from buying other items you want. \\
\hline & & To buy the __ you will have to forgo other items that you value. \\
\hline & & you will have to reduce other expenses. \\
\hline & & you will have to give up certain comforts. \\
\hline & \multirow{3}{*}{ Loss } & will bring you financial difficulty. \\
\hline & & will make you delay payment of other bills. \\
\hline & & , you will have to do activities you don't like. \\
\hline \multirow{7}{*}{ Valence } & \multirow{3}{*}{ Realization } & it's a sign that you are a successful person. \\
\hline & & Buy the __ will give you prominence with your friends and family. \\
\hline & & $\begin{array}{l}\text { The purchase of __ make you proud to be part of this product owners } \\
\text { group. }\end{array}$ \\
\hline & \multirow{4}{*}{ Wellness } & Buy the _ is important for your comfort. \\
\hline & & The purchase of __ will increase your wellness. \\
\hline & & The purchase of __ will bring you advantages. \\
\hline & & $\begin{array}{l}\text { The effort to buy the __ will be offset by the gain you will get from the } \\
\text { product. }\end{array}$ \\
\hline
\end{tabular}

Source: Authors (2021).

The last stage of scale development was the development of recommendations for its application. It was understood that the scale developed is adequate to verify the sacrifice of (not) buying different products, which may be goods, services, experiences and ideas.

\subsection{Experimental studies: hypotheses verification}

To verify the research hypotheses, three complementary experiments were conducted with undergraduate and graduate students. For these experiments, we used a factorial study (between-subjects) having as the independent variables (IVs) Valence (perception of benefit) and Instrumentality (perception of loss) and as the dependent variable (DV) the intention to sacrifice for (not) buying. As treatment levels, valence (low x high) versus instrumentality (low x high) was used.

The operation occurred through scenarios that presented hypothetical situations of the purchase of a smartphone (first two experiments) and a property (third experiment), in which participants were asked, according to the condition presented, their judgement about (not) performing the purchase of the good. This series of questions was used as an instrument to measure sacrifice for the purchase of goods and services: the scale developed in item 6.

To measure involvement with the product, the Personal Involvement Inventory (PII) scale developed by Zaichkowsky (1985, 1994) was used. In all experiments, the data were collected in person by the researchers. To test the hypotheses, parametric and nonparametric tests were performed, operationalized by structural equation modelling (SEM), Factor ANOVA, the Kruskal-Wallis Test and Quantis ANOVA.

\subsubsection{Experiment I: Sacrifice Health Insurance for Profit When Buying a Smartphone}

In Experiment I, data collection was performed in two private higher education institutions in a Brazilian capital. The sample consisted of 180 valid questionnaires, 45 for each type of treatment.

To answer hypothesis (H1), which posits that the decision to perform the sacrifice of (not) buying is formed by the 
relationship between Valence and Instrumentality, structural equation modelling (SEM) was used with the help of SmartPLS-2 software (Ringle, Wende \& Becker, 2015). To estimate the sacrifice model, the second-order dimensions of the BSI, Valence and Instrumentality scale and the purchase Intent variable were considered (Figure 4).

Figure 4 - Sacrifice Model for Buying (Experiment I).

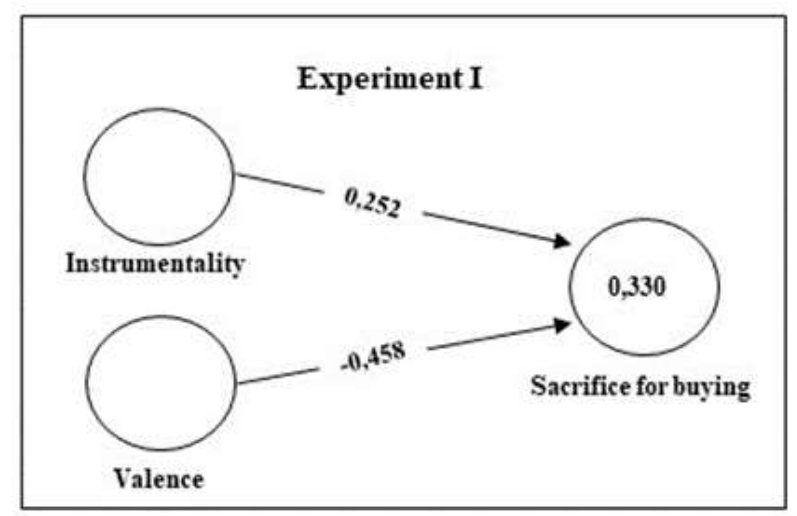

Source: Authors (2021).

Figure 4 shows the value of the linear regression path coefficient in the arrows, and within the circle of the endogenous variable, the value of R2 is displayed. The results of the structural model indicate that Valence has a strong negative effect on the intention to sacrifice for purchase, while Instrumentality has a strong positive effect. However, it is important to assess whether these relationships are significant $(\mathrm{p} \leq 0.05)$. In this sense, Student's t-test was calculated between the original data values and those obtained by the resampling technique. The $\mathrm{t}$-test values were above 1.96 , Instrumentality $(\mathrm{t}=$ $4,269)$ and Valence $(t=8,199)$, demonstrating that the effects are significant at the 0.05 level.

Looking for a greater amount of evidence to verify the results, the analyses of predictive validity using the StoneGeisser indicator (Q2) and effect size using the Cohen indicator (f2) were performed. The results show that the model has a medium degree of predictive relevance concerning the endogenous factor sacrifice for (not) buying $\left(\mathrm{Q}_{2}=0.291\right)$. Concerning the Cohen indicator (f2), the Instrumentality construct was characterized as of high importance for the model adjustment (f $2=$ 0.359). Valence was considered in the adopted reference (Cohen, 1988) as of medium importance. Thus, both results indicate that the constructs are essential for overall model fit.

However, it is relevant to verify the behaviour of these effects when involving another construct. Thus, it was verified whether involvement with the product alters the relationship between the components of the sacrifice of buying (Valence and Instrumentality) and the intention to purchase. The main results of this analysis are shown in Figure 5.

Figure 5 - Moderating Effect of Involvement (Experiment I).
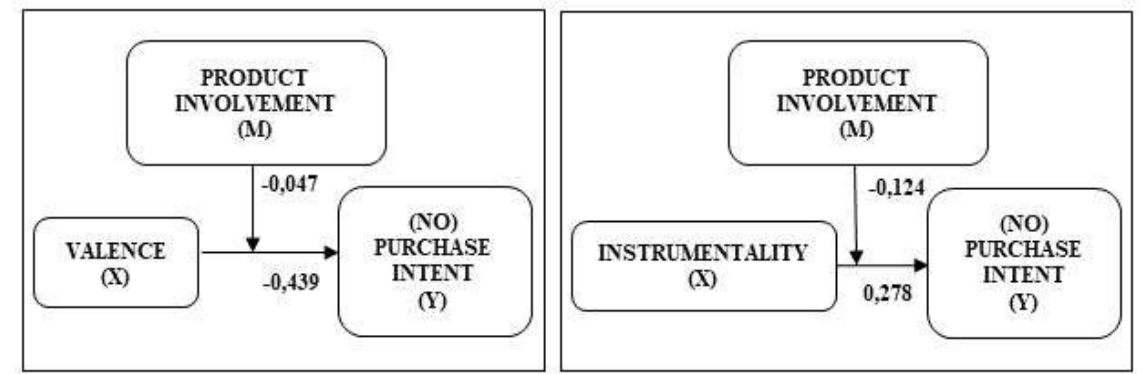

Source: Authors (2021). 
Analysis of the t-statistic for the interaction between the moderating effect of Involvement with the product on the relationship between Valence and Purchase Intent (0.387) shows that no support for a significant moderating effect was found. The verification of the relation of the significance of the effect between Instrumentality and Purchase Intention did not show support for the moderating effect of Involvement $(\mathrm{t}=0.777)$.

The results presented evidence that there is a strong effect of Valence and Instrumentality in the decision of whether to sacrifice for a purchase, as described in hypothesis (H1) and that Valence has a negative association with the intention to sacrifice for a purchase (hypothesis H1a). In the case of instrumentality, there was a positive association with sacrifice of buying (hypothesis H1b). Given the results obtained, evidence was found to confirm hypotheses H1a and H1b. Regarding the involvement with the product moderating the relationship between the dimensions of sacrifice (Valence and Instrumentality) and purchase intention, hypothesis (H2), the results do not show support for this assumption. Seeking other evidence for the verification of these hypotheses, new tests were performed through the Factorial Variance Analysis (Factor ANOVA and Kruskal-Wallis test), whose results indicated that there are no statistically valid differences between the treatment groups of the two variables.

The variance tests performed so far refer to measures of central position, typically the average, that can "hide" relevant differences between the lowest or highest group levels (Wilcox, 2017). Thus, it is important to verify, by other methods, potential differences between the different treatment levels used in the experiments. To this end, new tests were performed using Quantis ANOVA, considering the variables Valence and Purchase Intent and Instrumentality and Purchase Intent.

Table 3 - Quantis ANOVA - Experiment I.

\begin{tabular}{c|c|c}
\hline \multirow{2}{*}{$\mathrm{Q}$} & \multicolumn{2}{|c}{ p-value } \\
\cline { 2 - 3 } & Valence & Instrumentality \\
\hline 0,1 & 0,688 & 0,573 \\
0,2 & 0,728 & 0,545 \\
0,3 & 0,682 & 0,455 \\
0,4 & 0,545 & 0,105 \\
0,5 & 0,562 & 0,253 \\
0,6 & 0,425 & 0,120 \\
0,7 & 0,230 & 0,257 \\
0,8 & $\mathbf{0 , 0 2 3}$ & 0,350 \\
0,9 & $\mathbf{0 , 0 4 2}$ & 0,730 \\
\hline
\end{tabular}

Source: Authors (2021).

The results in Table 3 demonstrate that there is a significant effect on purchase intention provided by the higher levels of the Valence variable (8th and 9th deciles), demonstrating evidence that complements the information provided for hypothesis H1a. Regarding the Instrumentality variable, no differences were seen between treatment levels and purchase intention. For the following two experiments, the same analysis procedures previously presented were used; so as not to dwell on the analysis, the results are presented in a summarized form.

\subsubsection{Experiment II: Sacrifice to perform an unpleasant activity to satisfy personal desire to buy a new smartphone}

The second experiment had as scenario the performance of unpleasant activity to satisfy the personal desire to buy a new smartphone, which, in addition to personal satisfaction, would provide financial savings. Data collection was performed at 
a federal public higher education institution. The sample consisted of a group of 144 respondents. The results of estimating the sacrifice model for (not) buying using SEM (Figure 6) indicate that both Valence and Instrumentality have strong negative effects on the intention to sacrifice for a purchase.

Figure 6 - Sacrifice Model for Buying (Experiment II).

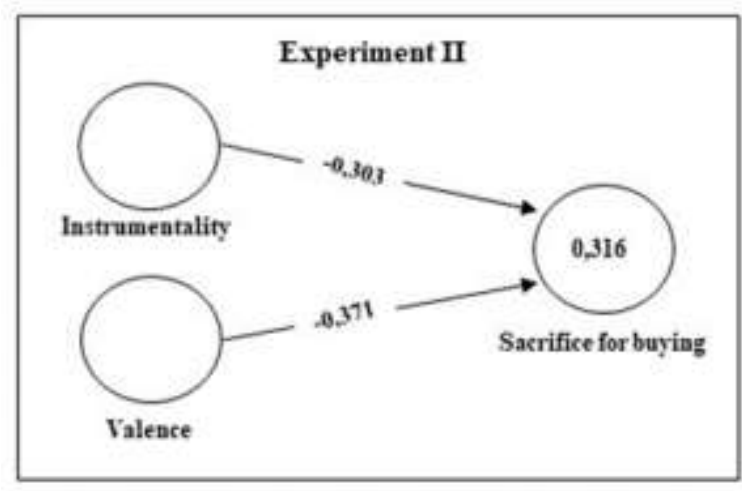

Source: Authors (2021).

However, it is important to assess whether these relationships are significant. Student's t-test calculation for the Instrumentality variable $(\mathrm{t}=0.973)$ was below 1.96 , demonstrating that the effects are not significant at the 0.05 level. Conversely, the test value for the Valence variable was significant $(\mathrm{t}=5.15)$.

The results showed that the model has a medium degree of predictive relevance in relation to the endogenous factor of sacrifice for buying $(\mathrm{Q} 2=0.243)$. Concerning the Cohen indicator (f2), the Instrumentality construct was characterized as not "useful" for the model adjustment ( $\mathrm{f} 2=-0.071)$. Thus, the results indicate that only Valence is relevant to the overall fit of the model.

Figure 7 - Moderating Effect of Involvement (Experiment II)

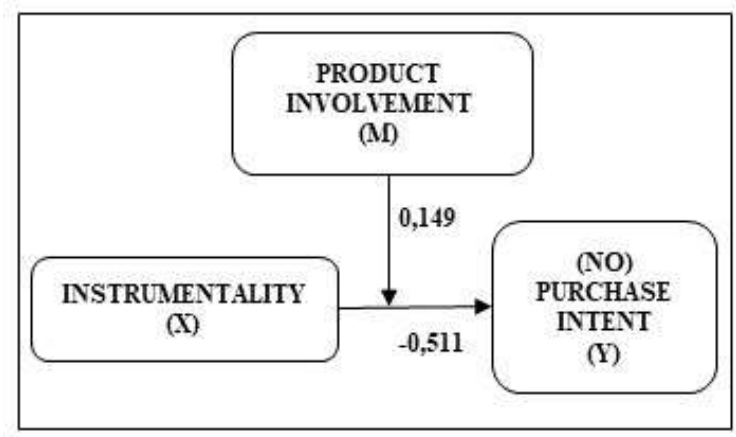

Source: Authors (2021).

Similar to Experiment I, it was examined whether involvement with the product alters the relationship between Valence and Purchase Intent. Figure 7 reveals that at a medium level of Involvement, the relationship between Valence and Purchase Intent was -0.511. Increasing the level of Involvement (a standard deviation point) would imply increasing the negative relationship between Valence and Purchase Intent $(-0.511-0.149=-0.660)$, which would make this relationship more important.

The t-statistic tests showed no support for the moderating effect. Given the results obtained, only evidence was found that there is a strong effect of Valence on the decision to sacrifice for a purchase, a fact that partially confirms the hypothesis 
(H1). Regarding hypothesis H1a, it was found that Valence has a negative association with the intention to sacrifice for a purchase, that is, the higher the Valence, the lower the perception of sacrifice for the purchase. Regarding hypothesis H1b, there was no support for its confirmation. The analysis of moderation of the variable Involvement with the relation between Valence and Purchase Intention was also not significant. Similarly, the Kruskal-Wallis test result confirmed the indication that there was no statistically valid difference in the different treatment levels of Valence $\left(\chi^{2}=2.815(1 \mathrm{gl}), \mathrm{p}=0.093\right)$ and Instrumentality $\left(\chi^{2}=1.654(1 \mathrm{~g}), \mathrm{p}=0.198\right)$.

Table 4 -Quantis ANOVA - Experiment II.

\begin{tabular}{c|c|c}
\hline \multirow{2}{*}{$\mathbf{q}$} & \multicolumn{2}{|c}{ p-value } \\
\cline { 2 - 3 } & Valence & Instrumentality \\
\hline 0,1 & 0,962 & 0,867 \\
0,2 & 0,477 & $\mathbf{0 , 0 2 3}$ \\
0,3 & 0,385 & $\mathbf{0 , 0 4 8}$ \\
0,4 & 0,092 & $\mathbf{0 , 0 2 3}$ \\
0,5 & 0,302 & $\mathbf{0 , 0 3 0}$ \\
0,6 & 0,313 & 0,645 \\
0,7 & $\mathbf{0 , 0 2 3}$ & 0,775 \\
0,8 & $\mathbf{0 , 0 2 2}$ & 0,785 \\
0,9 & 0,355 & 0,888 \\
\hline
\end{tabular}

Source: Authors (2021).

In addition, the Quantis ANOVA method (Table 4) demonstrated that there is a significant effect on Purchase Intent provided by the 7 th and 8th deciles of the Valence variable and at some of the levels of the Instrumentality variable (from 2 nd to 5th decile). Given these results, there is evidence that a change in the levels of the variables presented (hypotheses H1a and $\mathrm{H} 1 \mathrm{~b})$ affects the intention to sacrifice.

\subsubsection{Experiment III: Sacrifice of Selling a Car to Buy an Apartment}

Data collection from Experiment III took place in a private higher education institution in a Brazilian capital. The sample consisted of graduate students (specialization). A total of 160 questionnaires were valid, 40 for each type of treatment. The estimation results of the sacrifice model for (not) buying are presented in Figure 8.

Figure 8 - Sacrifice Model for Buying (Experiment III).

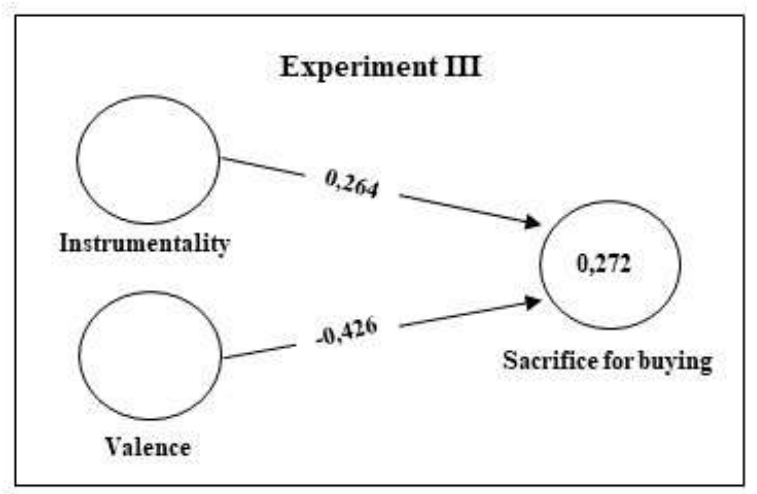

Source: Authors (2021).

Similar to Experiment I, an indication was obtained that Valence has a strong negative effect on the intention to 
sacrifice for a purchase, while Instrumentality has a strong positive effect. The model presented a medium degree of predictive relevance concerning the endogenous factor sacrifice for purchase $(\mathrm{Q} 2=0.291)$. Regarding the Cohen indicator (f2), it was found that Instrumentality ( $\mathrm{f} 2=0.245$ ) and Valence $(\mathrm{f} 2=0.240$ ) constructs were characterized as of medium importance for the model fit. This result differs from Experiment I, in which Instrumentality was considered of high importance.

In the moderation analysis, it was verified whether Involvement with the product alters the relationship between the components of the sacrifice for buying (Valence and Instrumentality) and the Purchase Intention. The results are shown in Figure 9.

Figure 9 - Moderating Effect of Involvement (Experiment III).
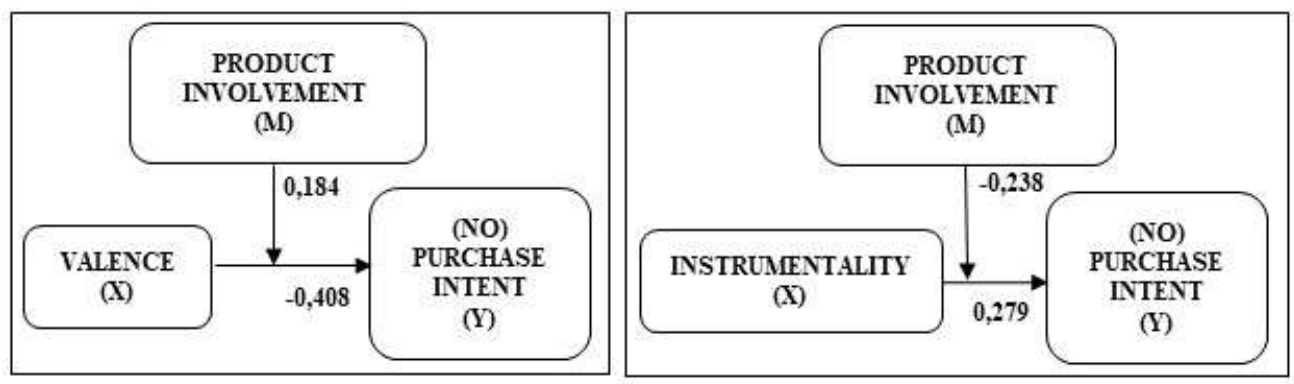

Source: Authors (2021).

It was identified that at a medium level of Involvement, the relationship between Valence and Purchase Intent is 0.408. Increasing the level of Involvement (a standard deviation point) would imply decreasing the negative relationship between Valence and Purchase Intent $(-0.408+0.184=-0.224)$, which would make this relationship less important. Analysis of the t-statistic for interaction between the moderating effect of Involvement with the product on the relationship between Valence and Purchase Intent $(t=0.757)$ is not supported for a significant moderating effect. In the case of Instrumentality, the increase in the level of Involvement (a standard deviation point) would practically eliminate the relationship between Instrumentality and Purchase Intent $(0.279-0.184=0.095)$. In the verification of significance, there was no support for the moderating effect of Involvement $(\mathrm{t}=0.634)$.

Given the results obtained, there was evidence confirming hypotheses H1a and H1b. Regarding the verification of Involvement with the product, moderating the relationship between the dimensions of the sacrifice (Valence and Instrumentality) and Purchase Intention, hypothesis $\mathrm{H} 2$, was not supported in its confirmation. As a way of expanding the verification of research hypotheses H1a and H1b, new statistical tests were performed. The results of the Factor ANOVA and the Kruskal-Wallis test indicated that there is no statistically valid difference between the different treatment levels of the variables. Using the Quantis ANOVA method (Table 5), it was found that in the variable Valence, no differences in treatment levels between the quantiles were identified. However, it was found that there is a significant effect on purchase intent provided by the 4th and 7th deciles of the variable Instrumentality, thus demonstrating evidence that partially confirms hypothesis H1b. 
Table 5 -Quantis ANOVA - Experiment III.

\begin{tabular}{r|c|c}
\hline \multirow{2}{*}{$\mathbf{q}$} & \multicolumn{2}{|c}{ p-value } \\
\cline { 2 - 3 } & Valence & Instrumentality \\
\hline 0,1 & 0,297 & 0,993 \\
0,2 & 0,462 & 0,427 \\
0,3 & 0,715 & 0,102 \\
0,4 & 0,805 & $\mathbf{0 , 0 3 8}$ \\
0,5 & 0,777 & 0,347 \\
0,6 & 0,687 & 0,328 \\
0,7 & 0,657 & $\mathbf{0 , 0 4 3}$ \\
0,8 & 0,695 & 0,390 \\
0,9 & 0,723 & 0,482 \\
\hline
\end{tabular}

Source: Authors (2021).

\section{Conclusion}

This study stands out for the contribution generated by the development of a sacrifice measurement instrument for (not) buying in the field of consumer behaviour. It has been found that the consumer is willing to make sacrifices for both buying and not buying products. A definition of the sacrifice for purchase was presented, and the consistency of the scale was tested in three experiments. In short, the results confirmed the existence of positive and negative elements in the sacrificial buying act. Such confirmation is important because they reaffirm and complement, in the context of consumption, some aspects of the classical approaches to sacrifice (Evans-Pritchard, 1956; Frazer, 1894; Tylor, 1871a) that considered the search for some benefit in making sacrifices.

It has not been shown in the three experiments that changes in Valence and Instrumentality levels alter the intention of a sacrificial purchase. However, it was identified in the first and second experiments that modifications in the Valence levels alter the purchase intention in the higher levels of this variable. The second and third experiments showed that changes in Instrumentality levels also affect the intention to sacrifice. Thus, there is evidence that different levels of Valence and Instrumentality affect purchase intent and that, as stated by Tylor (1871b), in the act of sacrifice, there is a process of exchange in which some kind of benefit is sought, a fact that also consolidates the definition of sacrifice presented as a willingness to give up something that has value (monetary or not) in order to obtain some benefit (emotional and/or material) of greater importance.

The study had some limitations, especially the use of written scenarios that, even with validation by experts and the use of pre-tests may have reduced participants' perception of reality, generating bias in some answers. It is recommended that future research use the scale presented here in situations that include services and experiences, as we only tested it with highinvolvement assets.

Finally, as a recommendation for future work and research, it is suggested that the perception of sacrifice of (not) buying of personal protection items in the pandemic period is verified and how social networks influence the perception of sacrifice for the purchase of products.

\section{References}

Bardin, L. (2011). Análise de Conteúdo. Edições 70.

Bataille, G. (1988). The Accursed Share: an essay on general economy. Zone Books.

Beldona, S., \& Kher, H. V. (2014). The Impact of Customer Sacrifice and Attachment Styles on Perceived Hospitality. Cornell Hospitality Quarterly, 56(4), 355-368. https://doi.org/doi:10.1177/1938965514559048. 
Belk, R. (2010). Sharing. Journal of Consumer Research, 36(5), 715-734. https://doi.org/10.1086/612649.

Bubbio, D. G. (2013). Kant's sacrificial turns. Int J Philos Relig, 73(2), 97-115. https://doi.org/10.1007/s11153-012-9380-3.

Carter, J. (2003). Understanding Religious Sacrifice: a Reader. Continuum.

Churchill, G. A. J. (1979). A paradigm for developing better measures of marketing constructs. Journal of Marketing Research, 16(1), 64-73. https://doi.org/10.1177/002224377901600110.

Clarke, J. (2007). The Four 'S's' of experience gift giving behaviour. International Journal of Hospitality Management, 26(1), 98-116. https://doi.org/10.1016/j.ijhm.2005.10.001.

Cohen, J. (1988). Statistical Power Analysis for the Behavioral Sciences. Lawrence Erlbaum Associates.

Costa, F. J. (2011). Mensuração e desenvolvimento de escalas: aplicações em administração. Ciência Moderna.

Cronin, J. J., Jr., Brady, M. K., \& Hult, T. M. (2000). Assessing the effects of quality, value, and customer satisfaction on consumer behavioral intentions in service environments. Journal of Retailing, 76(2), 193-218. https://doi.org/10.1016/s0022-4359(00)00028-2.

Day, L. C., \& Impett, E. A. (2017). Giving when it costs: How interdependent self-construal shapes willingness to sacrifice and satisfaction with sacrifice in romantic relationships. Journal of Social and Personal Relationships, 1-21. https://doi.org/10.1177/0265407517694965.

Desmonde, W. H. (1962). Magic, Myth, and Money: The Origin of Money in Religius Ritual. Free Press of Glencoe.

Dodds, W. B., Monroe, K. B., \& Grewal, D. (1991). Effects of price, brand, and store information on buyers' product evaluations. Journal of marketing research, 28(3), 307-319. https://doi.org/10.2307/3172866.

Evans-Pritchard, E. E. (1956). Nuer religion. Oxford: Clarendon Press.

Frazer, J. G. (1894). The Golden Bough - A Study in Comparative Religion. MacMillan and Co.

Gao, H., Zhang, Y., \& Mittal, V. (2015). Consumers' Local-Global Identity and Price Sensitivity: The Role of Sacrifice Mindset. In: AP - Asia-Pacific Advances in Consumer Research, 11 (eds. Echo Wen Wan and Meng Zhang), Duluth, MN: Association for Consumer Research, $302-303$.

Girard, R. (2005). Violence and the Sacred. Continuum.

Halbertal, M. (2012). On Sacrifice. Princeton University Press.

Hubert, H., \& Mauss, M. (1989). Sacrifice: Its Nature and Functions. The University of Chicago Press.

Hüttel, A., Ziesemer, F.; Peyer, M., \& Balderjahn, I. (2018). To purchase or not? Why consumers make economically (non-)sustainable consumption choices. Journal of Cleaner Production, 174(10), 827-836. https://doi.org/10.1016/j.jclepro.2017.11.019.

James, E. O. (1933). Origins of Sacrifice: A Study in Comparative Religions. John Murray.

Kearns, C.M. (2016), Theory and description in recent work on sacrifice. J R Anthropol Inst, 22: 412-414. https://doi.org/10.1111/1467-9655.12407

Keenan, D. K. (2005). The Question of Sacrifice. Bloomington: Indiana University Press.

Koch, E., \& Sauerbronn, J. (2018). To love beer above all things: An analysis of Brazilian craft beer subculture of consumption. Journal of Food Products Marketing, 1-25. https://doi.org/10.1080/10454446.2018.1431577.

Komiya, A., Ohtsubo, Y., Nakanishi, D., \& Oishi, S. (2019). Gift-giving in romantic couples serves as a commitment signal: Relational mobility is associated with more frequent gift-giving. Evolution and Human Behavior, 40(2), 160-166. https://doi.org/10.1016/j.evolhumbehav.2018.10.003.

Matear, M. A. (2014). The Role and Nature of Willingness to Sacrifice in Marketing Relationships. Queen's University.

Mauss, M. (2002). The Gift: The Form and Reason for Exchange in Archaic Societies. Routledge Classics.

Minowa, Y., \& Belk, R. W. (2019). Gifts, romance, and consumer culture. Routledge.

Mill, J. S. (1848). Principles of political economy. John W. Parker.

Miller, D. (1998). A Theory of Shopping. Polity Press.

Monroe, K. B., \& Krishnan, R. (1985). The effect of price on subjective product evaluations. In: Jacoby, J. and Olson, J. C. (Eds.), Perceived quality: how consumers view stores and merchandise. Lexington Books, Lexington, 209-232.

Moufahim, M. (2013). Religious gift giving. Marketing Theory, 13(4), 421-441. https://doi.org/10.1177/1470593113499698.

Netemeyer, R. G., Bearden, W. O., \& Sharma, S. (2003). Scaling Procedures: Issues and Applications. Sage Publications.

Pine, B. J., \& Gilmore, J. H. (2000). Satisfaction, sacrifice, surprise: three small steps create one giant leap into the experience economy. Strategy \& Leadership, 28(1), 18-23. https://doi.org/10.1108/10878570010335958. 
Research, Society and Development, v. 10, n. 13, e478101321556, 2021

(CC BY 4.0) | ISSN 2525-3409 | DOI: http://dx.doi.org/10.33448/rsd-v10i13.21556

Rahman, I., \& Reynolds, D. (2016). Predicting green hotel behavioral intentions using a theory of environmental commitment and sacrifice for the environment. International Journal of Hospitality Management, 52, 107-116. https://doi.org/10.1016/j.ijhm.2015.09.007.

Ramp, W. (2008). Transcendence, Liminality and Excess: Durkheim and Bataille on the Margins of 'Sociologie Religieuse'. Journal of Classical Sociology, 8(2), 208-232. https://doi.org/10.1177/1468795x08088872.

Ringle, C. M., Wende, S., \& Becker, J.-M. (2015). SmartPLS 3, 2015. http://www.smartpls.com.

Schmidt, B. E. (2013). Blood Sacrifice as a Symbol of the Paradigmatic Other - The Debate about Ebó-Rituals in the Americas. In: Sacrifice and Modern Thought. Oxford University Press, 197-213.

Sherry JR., J. F. (1983). Gift Giving in Anthropological Perspective. Journal of Consumer Research, 10(2), 157.

Sherry, J. F., \& Kozinets, R. V. (2007). Sacred iconography in secular space: alters, alters, and alterity at the Burning Man Project. In: Otnes, C. and Lowrey, T. M. Contemporary consumption rituals. Taylor \& Francis, 291-313.

Shilling, C, \& Mellor, P. A. (2013). Making things sacred: re-theorizing the nature and function of sacrifice in modernity. Journal of Classical Sociology, 13(3), 319-337. https://doi.org/10.1177/1468795X13480643.

Simmel, G. (1990). The Philosophy of Money. Routledge.

Smith, W. R. (1894). Lectures on the Religion of the Semites. Adam and Charles Black.

Teas, R. K., \& Agarwal, S. (2000). The effects of extrinsic product cues on consumers' perceptions of quality, sacrifice, and value. Journal of the Academy of marketing Science, 28(2), 278-290. https://doi.org/10.1177/0092070300282008.

Tylor, E. B.(1871a). Primitive Culture: Researches Into the Development of Mythology, Philosophy, Religion, Art, and Custom. (Vol. 2). John Murray.

Tylor, E. B. (1871b). Primitive Culture: Researches Into the Development of Mythology, Philosophy, Religion, Art, and Custom. (Vol. 1). John Murray.

Van Lange, P. A. M., Rusbult, C. E., Drigotas, S. M., Arriaga, X. B., Witcher, B. S., \& Cox, C. L. (1997). Willingness to sacrifice in close relationships. Journal of personality and social psychology, 72(6), 1373-1395. https://doi.org/10.1037/0022-3514.72.6.1373.

Watts, J. W. (2011). The Rhetoric of Sacrifice. In: Christian A. E., Ritual and Metaphor: Sacrifice in the Bible. Atlanta: Society of Biblical Literature, 3-16.

Wilcox, R. R. (2017). Global comparisons of medians and other quantiles in a one-way design when there are tied values. Communications in Statistics: Simulation and Computation, 46(4), 3010-3019. http://dx.doi.org/10.1080/03610918.2015.1071388.

Williams, J., Ashill, N., \&Thirkell, P. (2016). How is value perceived by children? Journal of Business Research, 69(12), 5875-5885. https://doi.org/10.1016/j.jbusres.2016.04.103.

Zaichkowsky, J. L. (1985). Measuring the Involvement Construct. Journal of Consumer Research, 12(3), 341. https://doi.org/10.1086/208520.

Zaichkowsky, J. L. (1994). The Personal Involvement Inventory: Reduction, Revision, and Application to Advertising. Journal of advertising, 23(4), 59-70. http://dx.doi.org/10.1080/00913367.1943.10673459.

Zeithaml, V. A. (1988). Consumer perceptions of price, quality, and value: a means-end model and synthesis of evidence. Journal of Marketing, 52(3), 2-22. 